Check for updates

Cite this: RSC Adv., 2018, 8, 14092

Received 26th March 2018

Accepted 30th March 2018

DOI: 10.1039/c8ra02606h

rsc.li/rsc-advances

\title{
Transfer hydrogenation of aldehydes catalyzed by silyl hydrido iron complexes bearing a [PSiP] pincer ligand $\uparrow$
}

\author{
Peng Zhang, ${ }^{a}$ Xiaoyan Li, (D) ${ }^{a}$ Xinghao Qi, ${ }^{a}$ Hongjian Sun, (D) *a Olaf Fuhr ${ }^{b}$ \\ and Dieter Fenske ${ }^{\mathrm{b}}$
}

\begin{abstract}
The synthesis and characterization of a series of silyl hydrido iron complexes bearing a pincer-type [PSiP] ligand $\left(2-\mathrm{R}_{2} \mathrm{PC}_{6} \mathrm{H}_{4}\right)_{2} \mathrm{SiH}_{2}\left(\mathrm{R}=\mathrm{Ph}(1)\right.$ and $\left.{ }^{i} \mathrm{Pr}(5)\right)$ or $\left(2-\mathrm{Ph}_{2} \mathrm{PC}_{6} \mathrm{H}_{4}\right)_{2} \mathrm{SiMeH}$ (2) were reported. Preligand 1 reacted with $\mathrm{Fe}\left(\mathrm{PMe}_{3}\right)_{4}$ to afford complex $\left(\left(2-\mathrm{Ph}_{2} \mathrm{PC}_{6} \mathrm{H}_{4}\right) \mathrm{SiH}\right) \mathrm{Fe}(\mathrm{H})\left(\mathrm{PMe}_{3}\right)_{2}$ (3) in toluene, which was structurally characterized by $\mathrm{X}$-ray diffraction. $\left(\left(2-\mathrm{Pr}_{2} \mathrm{PC}_{6} \mathrm{H}_{4}\right) \mathrm{SiH}\right) \mathrm{Fe}(\mathrm{H})\left(\mathrm{PMe}_{3}\right)(6)$ could be obtained from the reaction of preligand 5 with $\mathrm{Fe}\left(\mathrm{PMe}_{3}\right)_{4}$ in toluene. Furthermore, complex $\left(\left(2-{ }^{\mathrm{i}} \mathrm{Pr}_{2} \mathrm{PC}_{6} \mathrm{H}_{4}\right) \mathrm{Si}(\mathrm{OMe})\right)$ $\mathrm{Fe}(\mathrm{H})\left(\mathrm{PMe}_{3}\right)(7)$ was isolated by the reaction of complex 6 with 2 equiv. MeOH in THF. The molecular structure of complex 7 was also determined by single-crystal X-ray analysis. Complexes 3, 4, 6 and 7 showed good to excellent catalytic activity for transfer hydrogenation of aldehydes under mild conditions, using 2-propanol as both solvent and hydrogen donor. $\alpha, \beta$-Unsaturated aldehydes could be selectively reduced to corresponding $\alpha, \beta$-unsaturated alcohols. The catalytic activity of penta-coordinate complex 6 or 7 is stronger than that of hexa-coordinate complex 3 or 4 .
\end{abstract}

\section{Introduction}

Phosphine-based [PSiP] pincer complexes of transition metals have been studied extensively in recent years. ${ }^{1-5}$ In particular, they are involved as key intermediates in a variety of catalytic reactions of silicon compounds such as hydrosilylation, hydrocarboxylation of allenes and transfer hydrogenation. ${ }^{6}$ Because silyl ligands have stronger $\sigma$-donating characters and show a more potent trans-influence than commonly-used ligands in transition metal chemistry, ${ }^{7}$ the introduction of strong electron-donating and trans-labilizing silyl groups into tridentate ligand architectures may promote the formation of electron-rich and coordinatively-unsaturated complexes that exhibit novel reactivity with $\sigma$-bonds. ${ }^{8}$ Therefore, it is considered that silyl coordination compounds have potential applications in catalytic organic synthesis. In addition, changing phosphorus ligand would provide transition metal complexes with unique reactivity in catalytic reactions., ${ }^{9,10}$

${ }^{a}$ School of Chemistry and Chemical Engineering, Key Laboratory of Special Functional Aggregated Materials, Ministry of Education, Shandong University, Shanda Nanlu 27, 250100 Jinan, People's Republic of China. E-mail: hjsun@sdu.edu.cn

${ }^{b}$ Institut für Nanotechnologie (INT) und Karlsruher Nano-Micro-Facility (KNMF), Karlsruher Institut für Technologie (KIT), Hermann-von-Helmholtz-Platz 1, 76344 Eggenstein-Leopoldshafen, Germany

$\uparrow$ Electronic supplementary information (ESI) available: CIF files and a table giving crystallographic data for 3 and 7 and figures giving the original IR, ${ }^{1} \mathrm{H}$ NMR, ${ }^{31} \mathrm{P}$ NMR, ${ }^{13} \mathrm{C}$ NMR, ${ }^{29} \mathrm{Si}$ NMR spectra of the complexes and catalytic products. CCDC 1515026 and 1490870. For ESI and crystallographic data in CIF or other electronic format see DOI: 10.1039/c8ra02606h
Reduction of aldehydes and $\alpha, \beta$-unsaturated aldehydes to alcohols is a fundamental and indispensable process for synthesis of a wide range of alcohols because a lot of alcohols are useful products and precursors for pharmaceutical, agrochemical, material and fine chemical industries. ${ }^{11}$ In most cases the transformation of aldehydes and $\alpha, \beta$-unsaturated aldehydes to the related alcohols is a metal-catalyzed process. In this process, both $\mathrm{H}_{2}$ and alcohol can be used as reducing agents. In 2008, a series of new $\mathrm{Pt}(\mathrm{II})$ pincer complexes bearing a pincertype [PSiP] ligand $\left(2-{ }^{\mathrm{i}} \mathrm{Pr}_{2} \mathrm{PC}_{6} \mathrm{H}_{4}\right)_{2} \mathrm{SiH}_{2}$ were synthesized by Milstein's group. In addition, chloro-[PSiP]Pt complex was used to prepare silanol $\mathrm{Pt}(\mathrm{II})$ pincer complex by hydrolytic oxidation. ${ }^{12}$ In 2013 Beller and co-workers reported the catalytic hydrogenation of aldehyde with $\mathrm{H}_{2}$. This catalytic system is chemoselective against ketone. ${ }^{13}$ However, that reaction required an elevated temperature $\left(120^{\circ} \mathrm{C}\right)$ and a high $\mathrm{H}_{2}$ pressure (30 bar). In the same year, three-coordinate iron(II) and cobalt(II) complexes bearing three new $N$-phosphinoamidinate ligands were synthesized by Turculet's group and the iron(II) complexes as catalysts were used for hydrosilylation of carbonyl compounds with considerably low catalyst loading using 1 equiv. of $\mathrm{PhSiH}_{3} \cdot{ }^{14}$ In 2014, Morris utilized three kinds of iron complexes bearing tetradentate PNNP ligands to realize successfully transfer hydrogenation of ketones and imines..$^{15} \mathrm{In}$ 2015, Hu described new iron pincer complexes. These complexes could activate $\mathrm{H}_{2}$ and catalyze selective transfer hydrogenation of aldehydes at room temperature under a low pressure of $\mathrm{H}_{2}$ (4 bar). ${ }^{16}$ Compared to the traditional hydrogenation reaction by the highly flammable molecular hydrogen 
employing precious metal (such as Au, Pt and Pd) catalysts, ${ }^{17}$ the reduction of aldehydes and $\alpha, \beta$-unsaturated aldehydes via transfer hydrogenation using alcohol as both reaction solvent and source of hydrogen in the presence of cheap transition metal catalysts would be more promising because this is a safer, atom-efficient and environmentally-benign method. In most cases, 2-propanol as a conventional hydrogen donor solvent with a moderate boiling point $\left(82^{\circ} \mathrm{C}\right)$ serves as a reducing agent because it is stable and nontoxic. In addition, a strong base such as $\mathrm{KO}^{t} \mathrm{Bu}$ is usually necessary for most transfer hydrogenation processes in 2-propanol. In 2002 Crabtree developed a number of air-stable and moisture-insensitive Ir catalysts for efficient transfer hydrogenation. ${ }^{18}$ In 2006 Rashid and coworkers published several air-stable Ir complexes as effective catalysts for transfer hydrogenation of ketones under base-free conditions. ${ }^{19}$ In 2012 Colacino reported that four $\operatorname{Ir}(\mathrm{I})$ and $\operatorname{Ir}(\mathrm{III})$ $\mathrm{N}$-heterocyclic carbene (NHC) based complexes were used as catalysts in the reduction of aldehydes and ketones with glycerol. ${ }^{20}$

In this contribution, we have developed novel silyl hydrido iron [PSiP] pincer complexes for catalytic transfer hydrogenation of aldehydes and $\alpha, \beta$-unsaturated aldehydes under mild conditions, using 2-propanol as both solvent and hydrogen donor. Furthermore, we compared the catalytic effects of these complexes with different phosphorus groups on the results of catalytic reactions.

\section{Results and discussion}

\subsection{Reaction of $\mathrm{Fe}\left(\mathrm{PMe}_{3}\right)_{4}$ with $\left(2-\mathrm{Ph}_{2} \mathrm{PC}_{6} \mathrm{H}_{4}\right)_{2} \mathrm{SiRH}(\mathrm{R}=\mathrm{H}$ (1) and Me (2))}

In 2013, we reported the synthesis and characterization of a series of $\mathrm{Ni}, \mathrm{Co}$, and $\mathrm{Fe}$ complexes bearing a tridentate bis(phosphino)silyl ligand $\left(\left(2-\mathrm{Ph}_{2} \mathrm{PC}_{6} \mathrm{H}_{4}\right)_{2} \mathrm{SiMeH}\right)(2)$ (eqn (1)). The silyl hydrido iron(II) complex $\left(\left(2-\mathrm{Ph}_{2} \mathrm{PC}_{6} \mathrm{H}_{4}\right)_{2} \mathrm{SiMe}\right)$ $\mathrm{Fe}(\mathrm{H})\left(\mathrm{PMe}_{3}\right)_{2}$ (4) was found to be an excellent catalyst for hydrosilylation of aldehydes and ketones under mild conditions. $^{21}$

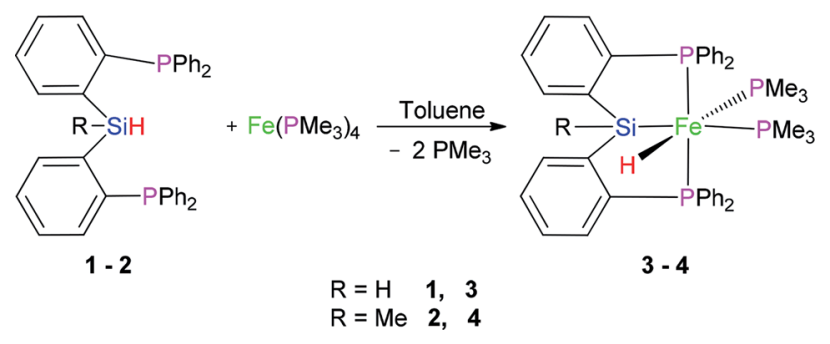

Preligand 1 was treated with one equiv. of $\mathrm{Fe}\left(\mathrm{PMe}_{3}\right)_{4}$ in toluene at room temperature (eqn (1)). Complex 3 was isolated in a yield of $79 \%$ from diethyl ether at $0{ }^{\circ} \mathrm{C}$. Orange bulk crystals of 3 suitable for X-ray diffraction were obtained from

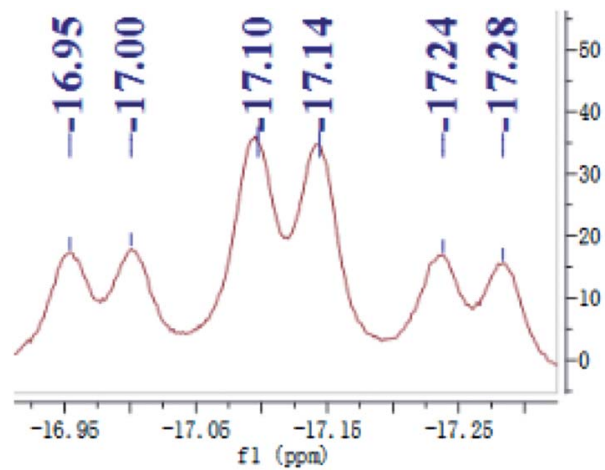

Fig. 1 The hydrido resonance of complex 3 at $-40{ }^{\circ} \mathrm{C}$.

a concentrated THF solution layered with $n$-pentane at $-20{ }^{\circ} \mathrm{C}$. In the IR spectrum of 3 , the typical $\nu(\mathrm{Fe}-\mathrm{H})$ stretching band of complex 3 is found at $1836 \mathrm{~cm}^{-1}$ while the $\nu(\mathrm{Fe}-\mathrm{H})$ stretching band of complex 4 is at $1870 \mathrm{~cm}^{-1} \cdot{ }^{19}$ This bathochromic shift $\left(34 \mathrm{~cm}^{-1}\right)$ is caused through the replacement of the Me group in complex 4 by the $\mathrm{H}$ atom in complex 3 because the density of the electron cloud at the iron center in complex $\mathbf{3}$ is smaller than that in complex 4 . The $\nu(\mathrm{Si}-\mathrm{H})$ of complex 3 was recorded at $1992 \mathrm{~cm}^{-1}$ while the $\nu(\mathrm{Si}-\mathrm{H})$ of preligand 1 was found at $2130 \mathrm{~cm}^{-1}$. In the ${ }^{1} \mathrm{H}$ NMR spectrum of 3 at $-40{ }^{\circ} \mathrm{C}$, the characteristic hydrido signal was found at $-\mathbf{1 7 . 1 2} \mathrm{ppm}$ as a pseudo td peak with the coupling constants $J_{\mathrm{PH}}=20$ and $70 \mathrm{~Hz}$ (Fig. 1). The split pattern of the hydrido signal of 3 is same with that of 4. ${ }^{19}$ The proton signal of the $\mathrm{Si}-\mathrm{H}$ bond of complex 3 appears at $5.72 \mathrm{ppm}$ as d peak while the resonance of the $\mathrm{Si}-\mathrm{H}$ bond in free preligand 1 was found at $5.87 \mathrm{ppm}$. Two signals at 0.97 and $0.45 \mathrm{ppm}$ for two $\mathrm{PMe}_{3}$ ligands in the ${ }^{1} \mathrm{H}$ NMR spectrum clearly indicate that the trimethylphosphine ligands are not chemically identical. It was found that two signals for $\mathrm{PMe}_{3}$ ligands and

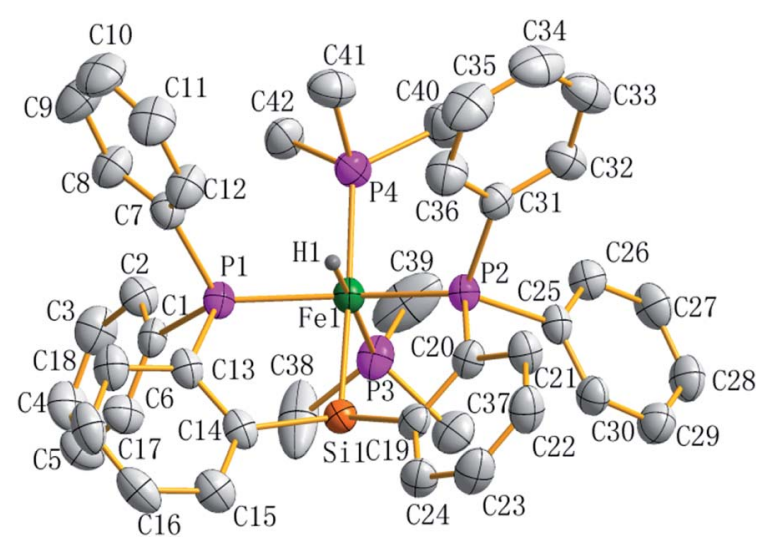

Fig. 2 ORTEP plot of complex 3 at the $50 \%$ probability level (most of hydrogen atoms are omitted for clarity). Selected bond lengths $(\AA)$ and angles (deg), Fe1-P1 2.2050(1), Fe1-P2 2.1932(1), Fe1-P3 2.2513(1), Fe1-P4 2.2510(1), Fe1-Si1 2.2831(1), Fe1-H 1.5778(6), P3-Fe1-H1 172.56(5), P1-Fe1-P3 105.91(4), P2-Fe1-P1 146.42(4), P2-Fe1-P3 103.29(4), P1-Fe1-Si1 81.84(4), P2-Fe1-Si1 82.44(4), P3-Fe1-Si1 89.02(4), Si1-Fe1-H1 83.76(4), C14-Fe1-Si1 110.65(1), C19-Si1-Fe1 109.49(1). 
one signal for $-\mathrm{P}^{\mathrm{i}} \mathrm{Pr}_{2}$ groups in the ${ }^{31} \mathrm{P}$ NMR of complex 3 at $-40{ }^{\circ} \mathrm{C}$ appeared at 5.2, 6.4 and $88.5 \mathrm{ppm}$ in the integral ratio of $1\left(\mathrm{PMe}_{3}\right): 1\left(\mathrm{PMe}_{3}\right): 2\left(-\mathrm{P}^{\mathrm{i}} \mathrm{Pr}_{2}\right)$, respectively. The solid state structure of complex 3 shows a distorted hexa-coordinate octahedral geometry (Fig. 2). The axial angle P3-Fe1-H1 is $172.6^{\circ}$, slightly deviating from $180^{\circ}$. [Si1Fe1P1P4P2] are in the equatorial plane. In comparison with the structural data, the molecular structure of complex 3 is similar to that of complex $4 .{ }^{19} \mathrm{Fe} 1-$ $\mathrm{H} 1$ distance is $1.5776 \AA$. Owing to the strong trans-influence of $\mathrm{H}$ and $\mathrm{Si}$ atom, the distances Fe1-P3 (2.2513(1) A) and Fe1-P4 $(2.2510(1) \AA)$ are significantly longer than the distances Fe1-P1

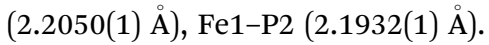

\subsection{Reaction of $\mathrm{Fe}\left(\mathrm{PMe}_{3}\right)_{4}$ with $\left(2-{ }^{\mathrm{i}} \mathrm{Pr}_{2} \mathrm{PC}_{6} \mathrm{H}_{4}\right)_{2} \mathrm{SiH}_{2}$ (5)}

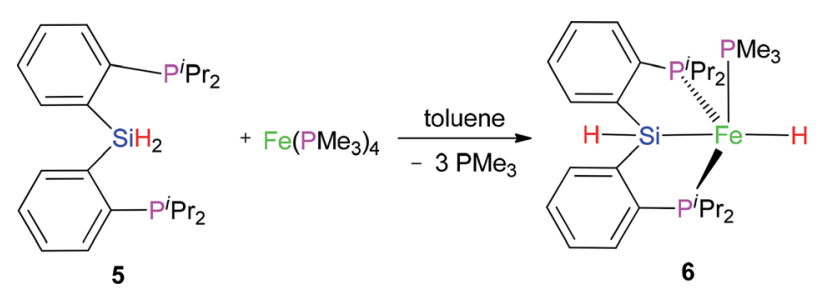

Complex 6 as pale yellow crystals was obtained from the reaction of 5 with $\mathrm{Fe}\left(\mathrm{PMe}_{3}\right)_{4}$ in toluene (eqn (2)). In the IR spectrum of complex 6 , instead of the signal at $2140 \mathrm{~cm}^{-1}(\nu(\mathrm{Si}-$ $\mathrm{H}$ ) for preligand 5), a new stretching band of the $\mathrm{Si}-\mathrm{H}$ bond was found at $2051 \mathrm{~cm}^{-1}$. This large bathochromic shift $\left(89 \mathrm{~cm}^{-1}\right)$ indicates that the activation of the $\mathrm{Si}-\mathrm{H}$ bond occurred. The $\nu(\mathrm{Fe}-\mathrm{H})$ was registered at $1841 \mathrm{~cm}^{-1}$. In the ${ }^{1} \mathrm{H}$ NMR spectrum of complex 6, the characteristic hydrido signal was found at $-14.23 \mathrm{ppm}$ as a td peak with the coupling constant $J_{\mathrm{PH}}=18$ and $72 \mathrm{~Hz}$. The proton signal of the $\mathrm{Si}-\mathrm{H}$ bond as multiplet appears at $5.91 \mathrm{ppm}$. Moreover, only one signal was identified at $1.11 \mathrm{ppm}$ for one $\mathrm{PMe}_{3}$ ligand. In the ${ }^{31} \mathrm{P}$ NMR of complex 6 , two sets of signals were distinguished at 29.0 and $120.0 \mathrm{ppm}$, respectively, corresponding to the two kinds of $\mathrm{P}$ atoms in the integral ratio of $1\left(\mathrm{PMe}_{3}\right): 2\left(-\mathrm{P}^{\mathrm{i}} \mathrm{Pr}_{2}\right)$. Regrettably, no crystals of complex 6 suitable for X-ray diffraction were obtained. Compared with hexa-coordinate complex 3 , the difference is that complex 6 is a penta-coordinated compound. Comparing isopropyl with phenyl group, the isopropyl group has a larger steric hindrance with stronger electron-donating ability than phenyl group. These two reasons make complex 6 pentacoordinated. Because complex $\mathbf{6}$ is a low-spin pentacoordination compound, which should have a tetragonal pyramid geometry. This can be further verified by the structure of complex 7 .

\subsection{Reaction of complex 6 with $\mathrm{MeOH}$}

The hydrido pincer iron(II) complex 6 could react with $\mathrm{MeOH}$ to afford another hydrido pincer iron(II) complex 7 (eqn (3)). In the IR spectrum of complex 7 , the $\mathrm{Fe}-\mathrm{H}$ vibration was found at
$1845 \mathrm{~cm}^{-1}$, a little bit larger than that $\left(1841 \mathrm{~cm}^{-1}\right)$ of complex 6 because the MeO-group has electron-withdrawing ability. In the ${ }^{1} \mathrm{H}$ NMR of complex 7 at $-40{ }^{\circ} \mathrm{C}$, the hydrido signal appeared at $-\mathbf{1 1 . 1 0} \mathrm{ppm}$ and split into a pseudo dddd peak due to the coupling effect of one $\mathrm{PMe}_{3}$ ligand and two chemically-identical $-\mathrm{P}^{\mathrm{i}} \mathrm{Pr}_{2}$ groups. Moreover, the proton signal of the $\mathrm{Si}-\mathrm{H}$ bond disappeared. There are two types of signals appearing at 22.2 and $106.2 \mathrm{ppm}$ with a relative integral ratio of $1\left(\mathrm{PMe}_{3}\right): 2(2 \times$ $\left.-\mathrm{P}^{\mathrm{i}} \mathrm{Pr}_{2}\right)$ in the ${ }^{31} \mathrm{P} \mathrm{NMR}$ of complex 7 . The related Pt chloride reacted with strong base to afford silyl ether Pt complex and the similar chemistry of Ru complex was also found by Stobart. ${ }^{12}$

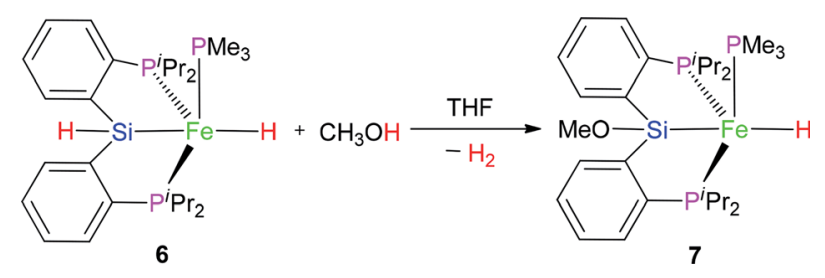

The molecular structure of complex 7 as a tetragonal pyramid $\left(\tau_{5}=0.0105\right)^{22}$ with an iron atom in the center was confirmed by single crystal X-ray diffraction (Fig. 3). In this molecular structure, P3 is the apex point and [Fe1P1P2Si1H] is the base plane of this tetragonal pyramid. Fe1-H1 distance is 1.60(3) A.

However, the similar reaction between complex 3 and $\mathrm{MeOH}$ did not occur. It is guessed that the difference in the reactivity between 3 and 6 might be caused by the vacant coordination in 6. This might allow for the coordination of $\mathrm{MeOH}$ (Scheme 1), followed by subsequent hydride protonation with the release of dihydrogen gas to form intermediate $\mathbf{6 A}$ (Scheme 1). The reductive elimination between $\mathrm{Fe}-\mathrm{Si}$ and $\mathrm{Fe}-\mathrm{O}$ bond affords intermediate 6B. Complex 7 was formed via oxidative addition of the $\mathrm{Si}-\mathrm{H}$ bond at the iron(0) center of 6B. Complex 7 as complex 6 is also a penta-coordinate low-spin iron(II) coordination compound.

\subsection{Catalytic application of iron hydrides 3, 4 and 6, 7 in transfer hydrogenation of aldehydes}<smiles>O=Cc1ccccc1</smiles>
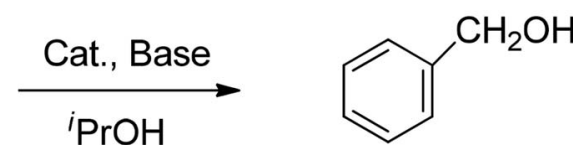

At the beginning, complex 7 as a catalyst was used to explore its catalytic application in the transfer hydrogenation of benzaldehyde (eqn (4)). The reaction was conducted with benzaldehyde as the test substrate using 2-propanol as the reaction solvent and source of hydrogen between $30-80{ }^{\circ} \mathrm{C}$. When the reaction was performed without catalyst, no reduction product was obtained in the control experiment (entry 1, Table 1). If the 


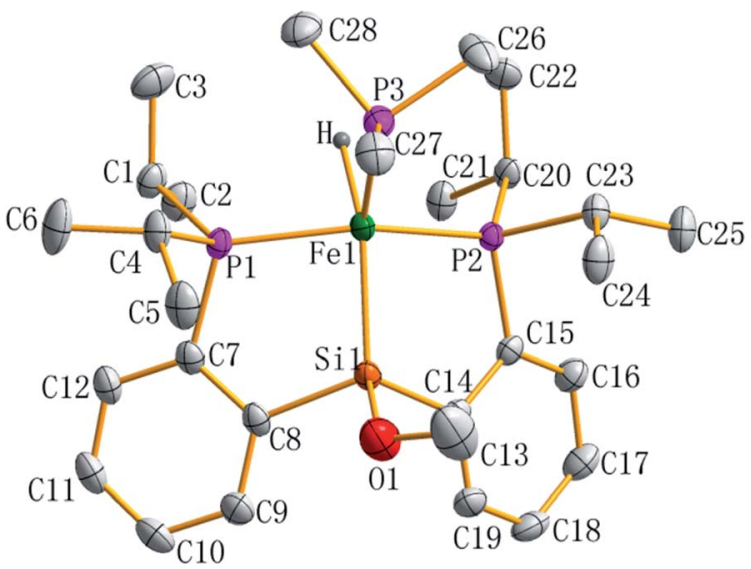

Fig. 3 ORTEP plot of complex 7 at the $50 \%$ probability level (hydrogen atoms are omitted for clarity). Selected bond lengths $(\AA)$ and angles (deg): Fe1-Si1 2.2712(6), Fe1-P1 2.1998(6), Fe1-P2 2.1997(6), Fe1-P3 2.2183(7), Fe1-H 1.60(3), Si1-O1 1.672(2), O1-C13 1.410(4); P2-Fe1P1 151.67(3), P1-Fe1-P3 101.43(2), P2-Fe1-P3 104.23(2), P1-Fe1-Si1 85.63(2), P2-Fe1-Si1 87.08(2), P3-Fe1-Si1 129.86(3), O1-Si1-Fe1 131.71(9), C13-O1-Si1 121.96(2), Si1-Fe1-H 151.5(1), Fe1-Si1-C14 105.94(7), C8-Fe1-Si1 107.05(7).

catalyst loading was $1 \mathrm{~mol} \%$, the conversion declined (entry 4 , Table 1). However, an excellent conversion (entry 3, Table 1) was observed in the presence of $2 \mathrm{~mol} \%$ of complex 7 . When the reaction temperature was $30^{\circ} \mathrm{C}$, the lower conversion was found (entry 11, Table 1). When the reaction temperature rose to $80^{\circ} \mathrm{C}$, the conversion declined sharply (entry 13, Table 1). And a grey precipitate appeared in the solution. It is guessed that the catalyst should have decomposed. Among $\mathrm{NaO}^{t} \mathrm{Bu}, \mathrm{Cs}_{2} \mathrm{CO}_{3}$, $\mathrm{K}_{2} \mathrm{CO}_{3}, \mathrm{Na}_{2} \mathrm{CO}_{3}, \mathrm{NaOH}$ and $\mathrm{KO}^{t} \mathrm{Bu}, \mathrm{KO}^{t} \mathrm{Bu}$ was the best base for this catalytic system (entries 3 and 6-10, Table 1). Without base, the reaction did not occur (entry 2, Table 1). At the given catalytic conditions, the reduction reaction was completely finished within $24 \mathrm{~h}$. The conversion was lower when reaction time was shorter than $24 \mathrm{~h}$ (entry 12, Table 1). According to the experimental results in Table 1 , the optimized catalytic reaction conditions can be summarized as follows: $60^{\circ} \mathrm{C}, 24$ hours and 2-propanol (5 mL), PhCHO (1.0 mmol) and $7(0.02 \mathrm{mmol})$. The mole ratio the catalyst to base should be $\mathbf{1}: \mathbf{1}$.

Under the optimized reaction conditions, we expanded the scope of the aldehyde substrates bearing different functional groups (Table 2). As shown in Table 2, the reactions with 2 mol\% of catalyst 7 at $60{ }^{\circ} \mathrm{C}$ in ${ }^{\mathrm{i}} \mathrm{PrOH}$ led to the corresponding alcohols with variable yields within $24 \mathrm{~h}$. The substrates with the electron-withdrawing substituents, such as 2- fluorobenzaldehyde, 2-chlorobenzaldehyde, 2-bromobenzaldehyde, 4-fluorobenzaldehyde, 4-chlorobenzaldehyde and 4-bromobenzaldehyde could be reduced to the corresponding alcohols by using $2 \mathrm{~mol} \%$ of catalyst in 24 hours (entries 3-8, Table 2). For the dihalogeno substrates, the aldehydes could be also converted to the corresponding products (entries 9 and 10, Table 2). When electron-donating group at para-position, moderate yield of the corresponding alcohol could be obtained from this catalytic system (entry 11, Table 2). With other aromatic aldehydes, moderate to good yields could be achieved (entries 13 and 14, Table 2). In addition, $\alpha, \beta$-unsaturated aldehydes could be selectively reduced to the corresponding $\alpha, \beta$ unsaturated alcohols in good yields (entries 15-19, Table 2)

Although complex 6 could also be used as catalyst for this catalytic system, the yields for the same substrates are lower than those of the reactions with complex 7 as catalyst in most cases. It is obvious that the introduction of MeO-group improves the catalytic activity of complex 7 . From Table 2, we also know that the yields of the transformation with complex 3 or $\mathbf{4}$ as catalyst are significantly lower than those with complex 6 or 7 as catalyst. This is also caused by the different coordination number in complex 3 or 4 and 6 or 7. The hexa-coordinate complexes $\mathbf{3}$ and $\mathbf{4}$ are more stable than penta-coordinate complexes 6 and 7. As a final result, complex 6 or 7 has stronger catalytic activity than complex 3 or $\mathbf{4}$. Under these optimized catalytic conditions, the ketones could not be reduced to the corresponding alcohols with complex $3,4,6$ or 7 as catalyst (entries $20-22$, Table 2). It is considered that the steric effect plays a decisive role in this case.

On the basis of the related report, ${ }^{16}$ a plausible mechanism for this catalytic system is proposed (Scheme 2). At first, complex 7 transforms to intermediate $7 \mathbf{A}$ via the coordination of carbonyl group in the aldehyde substrate. The nucleophilic attack of the hydrido hydrogen on the $\mathrm{C}$ atom of the carbonyl group gives rise to intermediate $\mathbf{7 B}$. Again, the ligand substitution of $\mathrm{RCH}_{2} \mathrm{O}$-group by $\mathrm{Me}_{2} \mathrm{HC}-\mathrm{O}$ - group affords intermediate $7 \mathrm{C}$ with the formation of the final product $\mathrm{RCH}_{2} \mathrm{OH}$. $\beta-\mathrm{H}$ elimination of the $\mathrm{Me}_{2} \mathrm{HC}-\mathrm{O}$-group provides acetone with the recovery of catalyst 7 .

\section{Conclusion}

The silyl hydrido $\mathrm{Fe}(\mathrm{II})$ complexs $\left(\left(2-\mathrm{Ph}_{2} \mathrm{PC}_{6} \mathrm{H}_{4}\right)_{2} \mathrm{HSi}\right)$ $\mathrm{Fe}(\mathrm{H})\left(\mathrm{PMe}_{3}\right)_{2}(3)$ and $\left(\left(2{ }^{\mathrm{i}} \mathrm{Pr}_{2} \mathrm{PC}_{6} \mathrm{H}_{4}\right)_{2} \mathrm{HSi}\right) \mathrm{Fe}(\mathrm{H})\left(\mathrm{PMe}_{3}\right)_{2}$ (6) were synthesized by the oxidative addition of the $\mathrm{Si}-\mathrm{H}$ bond of preligands $\left(2-\mathrm{R}_{2} \mathrm{PC}_{6} \mathrm{H}_{4}\right)_{2} \mathrm{SiH}_{2}\left(\mathrm{R}=\mathrm{Ph}(\mathbf{1})\right.$ and $\left.{ }^{\mathrm{i}} \mathrm{Pr}(5)\right)$ to $\mathrm{Fe}\left(\mathrm{PMe}_{3}\right)_{4}$ respectively. Treatment of 6 with $\mathrm{MeOH}$ resulted in the

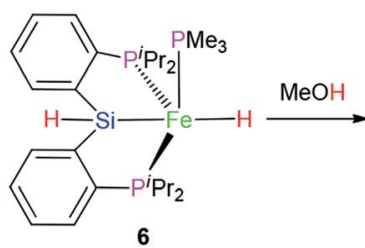

6
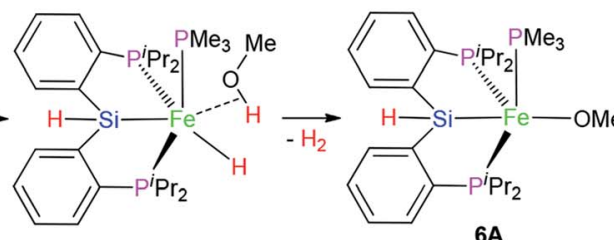

$6 \mathrm{~A}$

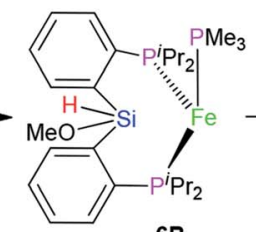

$6 B$

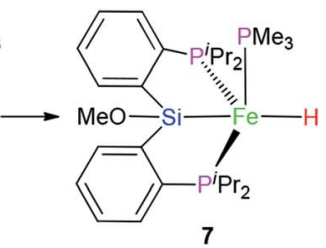

Scheme 1 
Table 1 Transfer hydrogenation of benzaldehyde with 7 as a catalyst ${ }^{a}$

\begin{tabular}{llllll}
\hline Entry & Loading (mol\%) & Base $^{b}$ & $T\left({ }^{\circ} \mathrm{C}\right)$ & Time $(\mathrm{h})$ & Conv. $^{c}(\%)$ \\
\hline 1 & 0 & $\mathrm{KO}^{t} \mathrm{Bu}$ & 60 & 24 & 0 \\
2 & 2 & $\mathrm{None}$ & 60 & 24 & 0 \\
3 & 2 & $\mathrm{KO}^{t} \mathrm{Bu}$ & 60 & 24 & $\geq 99$ \\
4 & 1 & $\mathrm{KO}^{t} \mathrm{Bu}$ & 60 & 24 & 81 \\
5 & 5 & $\mathrm{KO}^{t} \mathrm{Bu}$ & 60 & 24 & $\geq 99$ \\
6 & 2 & $\mathrm{NaO}^{t} \mathrm{Bu}$ & 60 & 24 & 83 \\
7 & 2 & $\mathrm{Cs}_{2} \mathrm{CO}_{3}$ & 60 & 24 & 57 \\
8 & 2 & $\mathrm{~K}_{2} \mathrm{CO}_{3}$ & 60 & 24 & 44 \\
9 & 2 & $\mathrm{Na}_{2} \mathrm{CO}_{3}$ & 60 & 24 & 21 \\
10 & 2 & $\mathrm{NaOH}^{\prime}$ & 60 & 24 & $\leq 10$ \\
11 & 2 & $\mathrm{KO}^{t} \mathrm{Bu}$ & 30 & 24 & 61 \\
12 & 2 & $\mathrm{KO}^{t} \mathrm{Bu}$ & 60 & 12 & 47 \\
13 & 2 & $\mathrm{KO}^{t} \mathrm{Bu}$ & 80 & 24 & 19
\end{tabular}

${ }^{a}$ PhCHO $(1.0 \mathrm{mmol}),{ }^{\mathrm{i}} \mathrm{PrOH}(5 \mathrm{~mL}) .{ }^{b} 7:$ base $=1: 1{ }^{c}$ Determined by GC with $n$-dodecane as internal standard.

formation of hydrido iron(II) complex $\left(\left(2{ }^{\mathrm{i}} \mathrm{Pr}_{2} \mathrm{PC}_{6} \mathrm{H}_{4}\right)_{2}(\mathrm{MeO}) \mathrm{Si}\right)$ $\mathrm{Fe}(\mathrm{H})\left(\mathrm{PMe}_{3}\right)$ (7) via elimination of $\mathrm{H}_{2}$. Furthermore, we demonstrated transfer hydrogenation of aldehydes to alcohols using 3, 4, 6 and 7 as catalysts with ${ }^{\mathrm{i}} \mathrm{PrOH}$ as both solvent and hydrogen source in moderate to good yields. This catalytic system could be operated under mild conditions and has tolerance for some substrates with different substituents. $\alpha, \beta-$ Unsaturated aldehydes could be selectively reduced to corresponding $\alpha, \beta$-unsaturated alcohols. The catalytic activity of penta-coordinate complex 6 or 7 is stronger than that of hexacoordinate complex 3 or 4.

\section{Experimental section}

\subsection{General procedures and materials}

Standard vacuum techniques were used in the manipulation of volatiles and air-sensitive materials. Solvents were dried by metal sodium and distilled under nitrogen before use. The ligand 1 and 5 were prepared according to the literature., ${ }^{9,10,12}$ $\mathrm{Fe}\left(\mathrm{PMe}_{3}\right)_{4}$ was prepared according to literature procedures. ${ }^{23}$ Infrared spectra $\left(4000-400 \mathrm{~cm}^{-1}\right)$, as obtained from Nujol mulls between $\mathrm{KBr}$ disks, were recorded on a Bruker ALPHA FT-IR instrument. ${ }^{1} \mathrm{H},{ }^{13} \mathrm{C}\{\mathrm{H}\},{ }^{31} \mathrm{P}\{\mathrm{H}\}$, and ${ }^{29} \mathrm{Si}\{\mathrm{H}\}$ NMR spectra were recorded using Bruker Avance $300 \mathrm{MHz}, 400 \mathrm{MHz}, 500 \mathrm{MHz}$ and $600 \mathrm{MHz}$ spectrometers with $\mathrm{C}_{6} \mathrm{D}_{6}$ or THF- $\mathrm{D}_{8}$ as the solvent at the corresponding temperature. Melting points were measured in capillaries sealed under $\mathrm{N}_{2}$ and were uncorrected. Elemented analyses were carried out on an Elementar Vario EL III instrument.

\subsection{Synthesis of 3}

At $-78{ }^{\circ} \mathrm{C}, \mathrm{Fe}\left(\mathrm{PMe}_{3}\right)_{4}(0.31 \mathrm{~g}, 0.86 \mathrm{mmol})$ in $20 \mathrm{~mL}$ toluene was added to a solution of $1(0.47 \mathrm{~g}, 0.86 \mathrm{mmol})$ in $40 \mathrm{~mL}$ of toluene. The mixture was warmed to room temperature and the color of solution has no obvious change. After stirred at room temperature for $24 \mathrm{~h}$, the solution was evaporated to dryness at reduced pressure. The residue was washed by two portions of $10 \mathrm{~mL}$ of
Table 2 Transfer hydrogenation of aldehydes using 3, 4, 6 or 7 as catalyst $^{a}$

\begin{tabular}{|c|c|c|c|}
\hline Entry & Substrate & Catalyst & $\begin{array}{l}\text { Isolated yield } \\
(\%)\end{array}$ \\
\hline \multirow{4}{*}{1} & & 7 & 98 \\
\hline & & 6 & 94 \\
\hline & & 3 & 70 \\
\hline & & 4 & 73 \\
\hline \multirow{4}{*}{2} & & 7 & 91 \\
\hline & & 6 & 83 \\
\hline & & 3 & 66 \\
\hline & & 4 & 74 \\
\hline \multirow{4}{*}{3} & & 7 & 89 \\
\hline & & 6 & 85 \\
\hline & & 3 & 72 \\
\hline & & 4 & 70 \\
\hline \multirow{3}{*}{4} & & 7 & 82 \\
\hline & $\mathrm{Cl}-$ & 6 & 83 \\
\hline & & 3 & 70 \\
\hline & & 4 & 71 \\
\hline \multirow{4}{*}{5} & & 7 & 79 \\
\hline & & 6 & 82 \\
\hline & & 3 & 73 \\
\hline & & 4 & 70 \\
\hline \multirow{4}{*}{6} & & 7 & 85 \\
\hline & & 6 & 84 \\
\hline & & 3 & 68 \\
\hline & & 4 & 72 \\
\hline \multirow{4}{*}{7} & & 7 & 84 \\
\hline & & 6 & 80 \\
\hline & & 3 & 73 \\
\hline & & 4 & 71 \\
\hline \multirow{4}{*}{8} & & 7 & 80 \\
\hline & & 6 & 81 \\
\hline & & 3 & 71 \\
\hline & & 4 & 66 \\
\hline \multirow{4}{*}{9} & & 7 & 75 \\
\hline & & 6 & 77 \\
\hline & & 3 & 65 \\
\hline & & 4 & 61 \\
\hline \multirow{4}{*}{10} & & 7 & 81 \\
\hline & & 6 & 83 \\
\hline & & 3 & 70 \\
\hline & & 4 & 66 \\
\hline \multirow{4}{*}{11} & & 7 & 80 \\
\hline & & 6 & 81 \\
\hline & & 3 & 64 \\
\hline & & 4 & 61 \\
\hline \multirow{4}{*}{12} & & 7 & 87 \\
\hline & & 6 & 84 \\
\hline & & 3 & 73 \\
\hline & & 4 & 76 \\
\hline \multirow{4}{*}{13} & & 7 & 95 \\
\hline & & 6 & 91 \\
\hline & & 3 & 77 \\
\hline & & 4 & 71 \\
\hline \multirow{4}{*}{14} & & 7 & 77 \\
\hline & & 6 & 75 \\
\hline & & 3 & 77 \\
\hline & & 4 & 75 \\
\hline
\end{tabular}


Table 2 (Contd.)

$\left.\begin{array}{lll}\text { Catalyst } & \text { Isolated yield } \\ (\%)\end{array}\right)$

${ }^{a}$ Substrate $(1.0 \mathrm{mmol}), \mathrm{KO}^{t} \mathrm{Bu}(0.02 \mathrm{mmol})$, catalyst $(0.02 \mathrm{mmol}),{ }^{\mathrm{i}} \mathrm{PrOH}$ $(5 \mathrm{~mL}), 60{ }^{\circ} \mathrm{C}, 24 \mathrm{~h} .{ }^{b}$ The reduced product is 3-phenylpro-2-yn-1-ol because the elimination occurred during the work-up.

cold THF. Complex $3(0.43 \mathrm{~g}, 0.47 \mathrm{mmol})$ was isolated as an orange powder in a yield of $79 \%$. Crystals suitable for X-ray diffraction were obtained from $n$-pentane solution through recrystallization. dec.: $>147{ }^{\circ} \mathrm{C}$. Anal. calc. for $\mathrm{C}_{42} \mathrm{H}_{48} \mathrm{FeP}_{4} \mathrm{Si}$ (760.62 $\mathrm{g} \mathrm{mol}^{-1}$ ): C, 66.32; H, 6.36. Found: C, 66.67; H, 6.49. IR (Nujol mull, cm $\left.{ }^{-1}\right): 3048$ (Ar-H), $1992(\mathrm{Si}-\mathrm{H}), 1836(\mathrm{Fe}-\mathrm{H}), 1583$ $(\mathrm{C}=\mathrm{C}), 940\left(\mathrm{PMe}_{3}\right) \mathrm{cm}^{-1} .{ }^{1} \mathrm{H}$ NMR $\left(500 \mathrm{MHz}, \mathrm{THF}-\mathrm{D}_{8}, 233 \mathrm{~K}, \delta /\right.$ $\mathrm{ppm}):-17.12\left(\mathrm{td},{ }^{2} J(\mathrm{PH})=20.0,{ }^{2} J(\mathrm{PH})=70.0 \mathrm{~Hz}, 1 \mathrm{H}, \mathrm{Fe}-\mathrm{H}\right)$, $0.45\left(\mathrm{~s}, \mathrm{PCH}_{3}, 9 \mathrm{H}\right), 0.97\left(\mathrm{~s}, \mathrm{PCH}_{3}, 9 \mathrm{H}\right), 5.72\left(\mathrm{~d},{ }^{2} J(\mathrm{PH})=10.0 \mathrm{~Hz}\right.$, 1H, SiH); 6.58 (s, 2H, Ar-H), 7.07-7.37 (m, 20H, Ar-H), 7.63 (s, $4 \mathrm{H}, \mathrm{Ar}-\mathrm{H}), 8.39$ (s, 2H, Ar-H). ${ }^{13} \mathrm{C}$ NMR $\left(75 \mathrm{MHz}, \mathrm{C}_{6} \mathrm{D}_{6}, 298 \mathrm{~K}, \delta /\right.$ ppm): 19.3 (s, $\left.\mathrm{PCH}_{3}\right), 125.4(\mathrm{~s}, \mathrm{Ar}), 126.0\left(\mathrm{t},{ }^{3} J(\mathrm{PC})=3.0 \mathrm{~Hz}, \mathrm{Ar}\right)$,

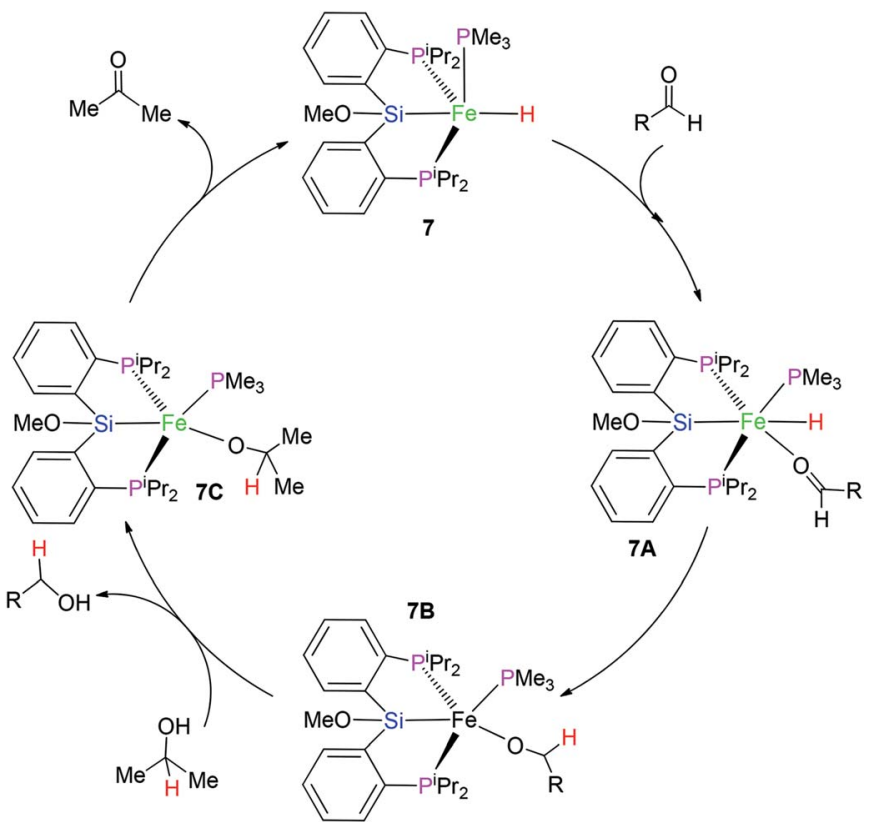

Scheme 2 A plausible mechanism for transfer hydrogenation.

$127.0\left(\mathrm{t},{ }^{3} J(\mathrm{PC})=1.5 \mathrm{~Hz}, \mathrm{Ar}\right), 127.4(\mathrm{~s}, \mathrm{Ar}), 132.8\left(\mathrm{t},{ }^{3} J(\mathrm{PC})=\right.$ 8.3 Hz, Ar), 133.2 (t, $\left.{ }^{3} J(\mathrm{PC})=9.0 \mathrm{~Hz}, \mathrm{Ar}\right) .{ }^{31} \mathrm{P}$ NMR $(202.5 \mathrm{MHz}$, THF-D $8,233 \mathrm{~K}, \delta / \mathrm{ppm}): 5.2\left(\mathrm{q}, J=30.4 \mathrm{~Hz}, \mathrm{PMe}_{3}, 1 \mathrm{P}\right), 6.4(\mathrm{~m}$, $\left.\mathrm{PMe}_{3}, 1 \mathrm{P}\right), 88.5\left(\mathrm{t}, J=20.3 \mathrm{~Hz}, \mathrm{PPh}_{2}, 2 \mathrm{P}\right) .{ }^{29} \mathrm{Si} \mathrm{NMR}(79.45 \mathrm{MHz}$, $\left.\mathrm{C}_{6} \mathrm{D}_{6}, 298 \mathrm{~K}, \delta / \mathrm{ppm}\right): 68.8(\mathrm{~s})$.

\subsection{Synthesis of 6}

To a brown yellow solution of $\mathrm{Fe}\left(\mathrm{PMe}_{3}\right)_{4}(0.40 \mathrm{~g}, 1.11 \mathrm{mmol})$ in $20 \mathrm{~mL}$ of toluene was added a solution of $5(0.42 \mathrm{~g}, 1.01 \mathrm{mmol})$ in $30 \mathrm{~mL}$ of toluene. The mixture was stirred at room temperature for $32 \mathrm{~h}$. During this period, the reaction solution turned yellow. The volatiles were removed by vacuum. The viscous residue was extracted with $n$-pentane and diethyl ether. The pale yellow crystals of $\mathbf{6}$ were obtained from diethyl ether at $0{ }^{\circ} \mathrm{C}$. Yield: $480 \mathrm{mg}$ (65\%). Crystals suitable for X-ray diffraction were obtained in pentane solution. dec.: $>127{ }^{\circ} \mathrm{C}$. Anal. calc. for $\mathrm{C}_{27} \mathrm{H}_{47} \mathrm{FeP}_{3} \mathrm{Si}\left(548.51 \mathrm{~g} \mathrm{~mol}^{-1}\right.$ ): C, 59.12; H, 8.64. Found: C, 58.87; H, 8.51. IR (Nujol mull, $\mathrm{cm}^{-1}$ ): 3058 (Ar-H), 2051 (Si-H), $1841(\mathrm{Fe}-\mathrm{H}), 1554(\mathrm{C}=\mathrm{C}), 950\left(\mathrm{PMe}_{3}\right) .{ }^{1} \mathrm{H}$ NMR $\left(300 \mathrm{MHz}, \mathrm{C}_{6} \mathrm{D}_{6}\right.$, $298 \mathrm{~K}, \delta / \mathrm{ppm}):-14.23\left(\mathrm{td},{ }^{2} J(\mathrm{PH})=18.0 \mathrm{~Hz},{ }^{2} J(\mathrm{PH})=72.0 \mathrm{~Hz}\right.$, $1 \mathrm{H}, \mathrm{Fe}-\mathrm{H}), 0.71\left(\mathrm{q},{ }^{2} J(\mathrm{PH})=6.0 \mathrm{~Hz}, \mathrm{PCHCH}_{3}, 6 \mathrm{H}\right), 0.84-0.89(\mathrm{~m}$, $\left.\mathrm{PCHCH}_{3}, 12 \mathrm{H}\right), 0.92\left(\mathrm{q},{ }^{2} J(\mathrm{PH})=6.0 \mathrm{~Hz}, \mathrm{PCHCH}_{3}, 6 \mathrm{H}\right), 1.11(\mathrm{~d}, J$ $\left.=3.0 \mathrm{~Hz}, \mathrm{PCH}_{3}, 9 \mathrm{H}\right), 1.75-1.89\left(\mathrm{~m}, \mathrm{PCHCH}_{3}, 2 \mathrm{H}\right), 2.28-2.40(\mathrm{~m}$, $\left.\mathrm{PCHCH}_{3}, 2 \mathrm{H}\right), 5.86-5.95$ (m, 1H, SiH); 6.95-6.99 (m, 2H, Ar-H), 7.04-7.09 (m, 2H, Ar-H), 7.14-7.16 (m, 2H, Ar-H), 8.03 (d, ${ }^{2} J(\mathrm{PH})$ $=6.0 \mathrm{~Hz}, 2 \mathrm{H}, \mathrm{Ar}-\mathrm{H}) .{ }^{13} \mathrm{C} \mathrm{NMR}\left(75 \mathrm{MHz}, \mathrm{C}_{6} \mathrm{D}_{6}, 298 \mathrm{~K}, \delta / \mathrm{ppm}\right)$ : $23.3\left(\mathrm{dd},{ }^{3} J(\mathrm{PC})=7.5 \mathrm{~Hz},{ }^{3} J(\mathrm{PC})=16.5 \mathrm{~Hz}, \mathrm{PCHCH}_{3}\right), 25.6(\mathrm{~s}$, $\left.\mathrm{PCHCH}_{3}\right), 26.6\left(\mathrm{q},{ }^{3} J(\mathrm{PC})=6.0 \mathrm{~Hz}, \mathrm{PCH}_{3}\right), 126.4(\mathrm{~s}, \mathrm{Ar}), 131.4(\mathrm{~s}$, $\mathrm{Ar}), 132.5\left(\mathrm{t},{ }^{3} J(\mathrm{PC})=9.0 \mathrm{~Hz}, \mathrm{Ar}\right), 133.3\left(\mathrm{t},{ }^{3} J(\mathrm{PC})=4.5 \mathrm{~Hz}, \mathrm{Ar}\right)$, $133.9\left(\mathrm{t},{ }^{3} J(\mathrm{PC})=4.5 \mathrm{~Hz}, \mathrm{Ar}\right), 143.5(\mathrm{~s}, \mathrm{Ar}), 155.0\left(\mathrm{t},{ }^{3} J(\mathrm{PC})=\right.$ $26.3 \mathrm{~Hz}, \mathrm{Ar}) .{ }^{31} \mathrm{P}$ NMR $\left(121 \mathrm{MHz}, \mathrm{C}_{6} \mathrm{D}_{6}, 298 \mathrm{~K}, \delta / \mathrm{ppm}\right): 29.0(\mathrm{t}, J=$ 
$\left.27.8 \mathrm{~Hz}, \mathrm{PMe}_{3}, 1 \mathrm{P}\right), 120.0$ (d, $\left.J=27.8 \mathrm{~Hz}, \mathrm{P}^{\mathrm{i}} \mathrm{Pr}_{2}, 2 \mathrm{P}\right) .{ }^{29} \mathrm{Si} \mathrm{NMR}$ (79.45 MHz, $\left.\mathrm{C}_{6} \mathrm{D}_{6}, 298 \mathrm{~K}, \delta / \mathrm{ppm}\right): 57.7$ (s).

\subsection{Synthesis of 7}

At $0{ }^{\circ} \mathrm{C}$, MeOH $(0.044 \mathrm{~g}, 1.31 \mathrm{mmol})$ in $20 \mathrm{~mL}$ of THF was combined with $6(0.38 \mathrm{~g}, 0.69 \mathrm{mmol})$ in $30 \mathrm{~mL}$ of THF. The solution was taken to room temperature and stirred for $24 \mathrm{~h}$. The volatiles were removed at reduced pressure. The residue was extracted with $n$-pentane and diethyl ether. Complex 7 (247 $\mathrm{mg}$ ) was isolated as pale yellow crystals in a yield of $62 \%$. Crystals suitable for X-ray diffraction were obtained from the $n$ pentane solution. dec.:> $123{ }^{\circ} \mathrm{C}$. Anal. calc. for $\mathrm{C}_{28} \mathrm{H}_{49} \mathrm{FeOP}{ }_{3} \mathrm{Si}$ (578.52 $\mathrm{g} \mathrm{mol}^{-1}$ ): C, 58.13; H, 8.54. Found: C, 58.40; H, 8.71. IR (Nujol mull, cm $\left.{ }^{-1}\right): 3053(\mathrm{Ar}-\mathrm{H}), 1845(\mathrm{Fe}-\mathrm{H}), 1583(\mathrm{C}=\mathrm{C}), 943$ $\left(\mathrm{PMe}_{3}\right) .{ }^{1} \mathrm{H}$ NMR $\left(500 \mathrm{MHz}, \mathrm{THF}-\mathrm{D}_{8}, 233 \mathrm{~K}, \delta / \mathrm{ppm}\right):-11.10$ $\left(\right.$ dddd, $\left.{ }^{2} J(\mathrm{PH})=90.0 \mathrm{~Hz}, 72.0 \mathrm{~Hz}, 45.0 \mathrm{~Hz}, 1 \mathrm{H}, \mathrm{Fe}-\mathrm{H}\right), 0.76$ (q, $\left.{ }^{2} J(\mathrm{PH})=5.0 \mathrm{~Hz}, \mathrm{PCHCH}_{3}, 6 \mathrm{H}\right), 0.84\left(\mathrm{q},{ }^{2} J(\mathrm{PH})=5.0 \mathrm{~Hz}\right.$, $\mathrm{PCHCH}_{3}, 6 \mathrm{H}$ ), 1.08 (q, $\left.{ }^{2} J(\mathrm{PH})=5.0 \mathrm{~Hz}, \mathrm{PCHCH}_{3}, 6 \mathrm{H}\right), 1.23$ (q, $\left.{ }^{2} J(\mathrm{PH})=5.0 \mathrm{~Hz}, \mathrm{PCHCH}_{3}, 6 \mathrm{H}\right), 1.43\left(\mathrm{~d},{ }^{2} J(\mathrm{PH})=5.0 \mathrm{~Hz}, \mathrm{PCH}_{3}\right.$, 9H), $1.99-2.05\left(\mathrm{~m}, \mathrm{PCHCH}_{3}, 2 \mathrm{H}\right), 2.72\left(\mathrm{t},{ }^{2} J(\mathrm{PH})=5.0 \mathrm{~Hz}\right.$, $\left.\mathrm{PCHCH}_{3}, 2 \mathrm{H}\right), 3.39\left(\mathrm{~s},-\mathrm{OCH}_{3}, 3 \mathrm{H}\right), 7.17\left(\mathrm{t},{ }^{2} J(\mathrm{PH})=5.0 \mathrm{~Hz}, 2 \mathrm{H}\right.$, $\mathrm{Ar}-\mathrm{H}), 7.25\left(\mathrm{t},{ }^{2} J(\mathrm{PH})=5.0 \mathrm{~Hz}, 2 \mathrm{H}, \mathrm{Ar}-\mathrm{H}\right), 7.39\left(\mathrm{~d},{ }^{2} J(\mathrm{PH})=\right.$ 10.0 Hz, 2H, Ar-H), $7.83\left(\mathrm{~d},{ }^{2} J(\mathrm{PH})=5.0 \mathrm{~Hz}, 2 \mathrm{H}, \mathrm{Ar}-\mathrm{H}\right) .{ }^{31} \mathrm{P}$ NMR (202.5 MHz, THF-D $, 298 \mathrm{~K}, \delta / \mathrm{ppm}): 22.2\left(\mathrm{t}, J=24.3 \mathrm{~Hz}, \mathrm{PMe}_{3}\right.$, 1P), 106.2 (dd, $\left.J=8.1 \mathrm{~Hz}, J=24.3 \mathrm{~Hz}, \mathrm{P}^{\mathrm{i}} \mathrm{Pr}_{2}, 2 \mathrm{P}\right) .{ }^{13} \mathrm{C} \mathrm{NMR}(100$ $\left.\mathrm{MHz}, \mathrm{C}_{6} \mathrm{D}_{6}, 298 \mathrm{~K}, \delta / \mathrm{ppm}\right): 17.1\left(\mathrm{~s}, \mathrm{PCH}_{3}\right), 19.9\left(\mathrm{~s}, \mathrm{PCHCH}_{3}\right)$, $30.0\left(\mathrm{~s}, \mathrm{PCHCH}_{3}\right), 67.5\left(\mathrm{~s}, \mathrm{OCH}_{3}\right), 126.48$ (s, Ar), 128.83 (s, Ar), $131.2\left(\mathrm{t},{ }^{3} J(\mathrm{PC})=8.0 \mathrm{~Hz}, \mathrm{Ar}\right), 143.1\left(\mathrm{t},{ }^{3} J(\mathrm{PC})=27.0 \mathrm{~Hz}, \mathrm{Ar}\right)$, $157.81\left(\mathrm{t},{ }^{3} J(\mathrm{PC})=23.0 \mathrm{~Hz}, \mathrm{Ar}\right) .{ }^{29} \mathrm{Si} \mathrm{NMR}\left(79.45 \mathrm{MHz}, \mathrm{C}_{6} \mathrm{D}_{6}, 298\right.$ $\mathrm{K}, \delta / \mathrm{ppm}): 42.2(\mathrm{~s})$.

\subsection{General procedure for transfer hydrogenation of aldehydes}

In $25 \mathrm{~mL}$ Schlenk tube containing a solution of $7(0.02 \mathrm{mmol})$ in $5 \mathrm{~mL}$ of ${ }^{\mathrm{i}} \mathrm{PrOH}$ were added an aldehyde $(1.0 \mathrm{mmol})$ and $\mathrm{KO}^{t} \mathrm{Bu}$ $(0.02 \mathrm{mmol})$. The reaction mixture was stirred at $60{ }^{\circ} \mathrm{C}$. The organic product was extracted with $\mathrm{Et}_{2} \mathrm{O}$ and further purified by chromatography.

\subsection{X-Ray structure determinations}

Crystallographic data for complexes 3 and 7 are summarized in the ESI. $\uparrow$ Intensity data were collected on a Stoe Stadi Vari Cu diffractometer. Using Olex $2,{ }^{24}$ the structure was solved with ShelXS ${ }^{25}$ structure solution program using direct methods and refined with the ShelXL ${ }^{26}$ refinement package using least squares minimization. CCDC-1515026 (3) and 1490870 (7) contain supplementary crystallographic data for this paper.

\section{Conflicts of interest}

There are no conflicts to declare.

\section{Acknowledgements}

We gratefully acknowledge the financial support by NSF China No. $21572119 / 21372143$.

\section{References}

1 E. Morgan, D. F. Maclean, R. McDonald and L. Turculet, J. Am. Chem. Soc., 2009, 131, 14234-14236.

2 H. W. Suh, L. M. Guard and N. Hazzri, Polyhedron, 2014, 84, 37-43.

3 D. F. Maclean, R. Mcdonald, M. J. Ferguson, A. J. Caddell and L. Turculet, Chem. Commun., 2008, 41, 5146-5148.

4 J. Takaya, N. Kirai and N. Iwasawa, J. Am. Chem. Soc., 2011, 133, 12980-12983.

5 E. Suarez, P. Plou, D. G. Gusev, M. Matin and E. Sola, Inorg. Chem., 2017, 56, 7190-7199.

6 J. Y. Corey, Chem. Rev., 2011, 111, 863-1071.

7 J. Zhu, Z. Lin and T. B. Marder, Inorg. Chem., 2005, 44, 93849390.

8 H. Fang, Y. K. Choe, Y. Li and S. Shimada, Chem. Asian J., 2011, 6, 2512-2521.

9 M. T. Whited, A. M. Deetz, J. W. Boerma, D. E. DeRosha and D. E. Janzen, Organometallics, 2014, 33, 5070-5073.

10 J. C. DeMott, W. Gu, B. J. McCulloch, D. E. Herbert, M. D. Goshert, J. R. Walensky, J. Zhou and O. V. Ozerov, Organometallics, 2015, 34, 3930-3933.

11 (a) C. Mohr, H. Hofmeister, M. Lucas and P. Claus, Chem. Eng. Technol., 2000, 23(4), 324-328; (b) L. A. Saudan, Acc. Chem. Res., 2007, 40, 1309-1319; (c) P. Gallezot and D. Richard, Catal. Rev.: Sci. Eng., 1998, 40(1\&2), 81-126.

12 (a) E. E. Korshin, G. Leitus, L. J. W. Shimon, L. Konstantinovski and D. Milstein, Inorg. Chem., 2008, 47, 7177-7189; (b) S. R. Stobart, X. Zhou, R. Cea-Olivares and A. Toscano, Organometallics, 2001, 20, 4766-4768.

13 G. Wienhöfer, F. A. Westerhaus, K. Junge, R. Ludwig and M. Beller, Chem. - Eur. J., 2013, 19, 7701-7707.

14 A. J. Ruddy, C. M. Kelly, L. S. M. Crawford, C. A. Wheaton, O. L. Sydora, B. L. Small, M. Stradiotto and L. Turculet, Organometallics, 2013, 32, 5581-5588.

15 P. E. Sues, K. Z. Demmans and R. H. Morris, Dalton Trans., 2014, 43, 7650-7667.

16 S. Mazza, R. Scopelliti and X. Hu, Organometallics, 2015, 34, 1538-1545.

17 (a) Y. C. Hong, K. Q. Sun, G. R. Zhang, R. Y. Zhong and B. Q. Xu, Chem. Commun., 2011, 47, 1300-1302; (b) K. Q. Sun, Y. C. Hong, G. R. Zhang and B. Q. Xu, ACS Catal., 2011, 1, 1336-1346; (c) P. Claus, Top. Catal., 1998, 5, 51-62.

18 M. Albrecht, J. R. Miecznikowski, A. Samuel, J. W. Faller and R. H. Crabtree, Organometallics, 2002, 21, 3596-3604.

19 Z. E. Clarke, P. T. Maragh, T. P. Dasgupta, D. G. Gusev, A. J. Lough and K. Abdur-Rashid, Organometallics, 2006, 25, 4113-4117.

20 A. Azua, J. A. Mata, E. Peris, F. Lamaty, J. Martinez and E. Colacino, Organometallics, 2012, 31, 3911-3919.

$21 \mathrm{~S} . \mathrm{Wu}, \mathrm{X} . \mathrm{Li}, \mathrm{Z}$. Xiong, W. Xu, Y. Lu and H. Sun, Organometallics, 2013, 32, 3227-3237. 
22 A. W. Addison, T. N. Rao, J. Reedijk, J. van Rijn and G. C. Verschoor, J. Chem. Soc., Dalton Trans., 1984, 3, 13491356.

23 (a) H. H. Karsch, Chem. Ber., 1977, 110, 2699-2711; (b) R. Hammer and H. F. Klein, Zeitschrift für Naturforschung, 1977, 32b, 138-143.
24 O. V. Dolomanov, L. J. Bourhis, R. J. Gildea, J. A. K. Howard and H. Puschmann, J. Appl. Crystallogr., 2009, 42, 339-341. 25 G. M. Sheldrick, Acta Crystallogr., 2008, A64, 112-122.

26 G. M. Sheldrick, Acta Crystallogr., 2015, C71, 3-8. 